\title{
"GREEN" INFRASTRUCTURE OF THE ECONOMY OF RECREATIONAL NATURE USE
}

\author{
Natalya Andryeyeva ${ }^{1}$, Sergey Nezdoyminov ${ }^{2}$, Olena Martyniuk ${ }^{3}$
}

\begin{abstract}
The purpose of the article is to identify environmental risks and economic problems of the formation of the national ecological network and development directions of "green" tourism in the recreational and protected areas in the context of the transition to sustainable development. Methodology. The abstract-logical method (in the process of theoretical generalizations and the formation of conclusions); methods of statistical, structural, and factor analysis (in the process of studying the structure and dynamics of the development of ecological networks); empirical research methods (comparison) are used. In preparing the article, the authors analysed the works of scientists, which reflect approaches to the definition of the role of ecological networks, the natural potential of recreational areas in the transition to sustainable development. Changes in nature are evaluated through indicators of the dynamics of areas of the nature reserve fund, which form the national ecological network. Results. According to the results of the study, it is determined that the area of Ukrainian land belonging to the components of the national ecological network increased by 201.3 thousand hectares in comparison with 2000, but since 2014 this area has decreased by 0.6 thousand hectares. The area of forests and forest cover area increased by 2.8 thousand hectares, and the area of grassland and pasture fell by 7.8 thousand hectares. There is a tendency to increase the area of arable land, since 2014 it has increased by 15.8 thousand hectares and is 32541.3 thousand hectares. Compared to 2014 , the area of land under open development, quarries, mines, and related structures (157.1 thousand hectares) has increased by 0.8 thousand hectares and the land area used for transport and communication ( 496.8 thousand hectares) has increased (by 0.1 thousand hectares). In 2016, 32.5 billion UAH were spent on the protection of the environment by enterprises, organizations, and institutions of Ukraine, and in $2015-24.6$ billion UAH respectively. Practical implications. The necessity of elaboration of regional measures to develop "green infrastructure" of ecosystem services is determined. In the regions of Ukraine, it is necessary to develop balanced approaches to the use of the potential of nature conservation area of tourist nature use, international experience of implementing cross-border tourism projects in the Carpathian National Nature Park, and to form integrated investment regional tourism projects of ecological orientation. State policy in the field of recreational nature management should regulate the development of recreation and tourism sphere, first of all, in view of compliance with the requirements of ecologically balanced use of natural resources and ecologically balanced development of territories. The introduction of green tourism development lines will have a positive effect on the formation of ecological networks. Particularly, these measures are necessary to find additional investments for environmental protection measures and the development of ecological networks in Ukraine. Value/originality. In regions of Ukraine, it is necessary to begin work on the creation of a network of hiking and cycle routes in nature protection recreational territories and in regional nature parks. Their operation will enable the development of ecological networks, green tourism, and ecological areas of hospitality in the country.
\end{abstract}

Key words: ecological networks, sustainable development, natural potential, recreational territories, nature management, region.

JEL Classification: Q01, Q26, Q56, R11, L83

\footnotetext{
Corresponding author:

${ }^{1}$ Institute for Market Problems and Economic \& Ecological Research of the National Academy of Sciences of Ukraine, Ukraine.

E-mail: andreevann@ukr.net

${ }^{2}$ Odessa National Economic University, Ukraine.

E-mail: 2072945@gmail.com

${ }^{3}$ Odessa National Academy of Food Technologies, Ukraine.

E-mail: lena.martynyuk@gmail.com
} 


\section{Introduction}

The issue of the formation of ecological networks, the development of nature tourism in the recreational territories of Ukraine for many years remains extremely important, first of all, in terms of ensuring sustainable and balanced economic development of the country in the long run. Implementation of EU environmental directives in the field of climate change and protection of the ozone layer is taking place in the country, which allows the use of possibilities of the Association Agreement between Ukraine and the EU to improve the state of the environment. The main task of state and regional management in the conditions of sustainable development is the structural restructuring of the economy on the basis of the mandatory integration of environmental policy into the strategy of economic reforms. In the regions of the state, there is a significant revival of international relations in the field of nature conservation and recreational use of natural resources. Ukraine has joined a number of important international conventions and has assumed certain responsibilities, for which a number of government documents were adopted - on the concept of biodiversity conservation, on wetlands of national importance, etc. The exchange of international experience has intensified, and joint research has become commonplace, including on the creation of transboundary nature conservation objects.

One of the directions of the implementation of the state environmental policy is the development of an ecological network in Ukraine aimed at preserving the landscape and biological diversity and creating new objects of the Nature Reserve Fund (NRF). The increase in the area of the NRF, which according to the Program for the Formation of Ecological Network in 2020 will be $15 \%$ of our country's territory (now about $6 \%$ ), should take place taking into account the ways of migration and distribution of plant and animal species (so-called ecocorridors). At the same time, financing of the complex of measures envisaged by the Program for the formation of the National Ecological Network at the expense of the state budget of Ukraine, as well as enterprises of all forms of ownership, is not sufficient. Measures of the National Program of the Ecological Network of Ukraine to increase the area of lands with natural landscapes to the level sufficient to preserve their diversity in the regions of Ukraine require additional investment.

\section{Materials and methods}

Over the past years, environmental activities, problems in the formation of ecological networks have become the object of various studies. In preparing the article, the authors studied works of scientists, which reflect approaches to the definition of the role of natural potential in the strategy of sustainable development of territories. Works of foreign researchers have the methodological significance for building an ecological network in developing countries (Graham Bennett, 2004; Rob H. G. Jongman, Mart Külvik, and Ib Kristiansen, 2004; Paul Opdam, Eveliene Steingröver, and Sabine Van Rooij, 2006).

The following articles are devoted to the formation of the ecological network at the national level: Yu. R. Sheliah-Sosonko (Sheliah-Sosonko, 1999; SheliahSosonko, Tkachenko, Andriyenko, Movchan, 2005), where the authors proposed one of the first general schemes for the formation of the national ecological network of Ukraine, having developed scientific proposals for the improvement of the scheme for the formation of its natural territories with varying degrees of anthropogenic influence; H. I. Denysyk (Denysyk, 2010), where attention was drawn to the anthropogenic landscapes of ecological networks; V. M. Shvaiko, V. V. Maniuk (Shvaiko, Maniuk, 2017), who proposed an algorithm for the formation of a subregional ecological network using the QGIS software. Regional problems of sustainable development of natural potential and ecological risks in the field of tourism were considered by O. V. Serova, A. F. Kulagina (Serova and Kulagina, 2014); Izakovičová Z., Świąder M. (Izakovičová and Świąder, 2017) conducted research on the problems of the formation of ecological networks in Slovakia and Poland; and many other scientists.

The abstract-logical method (in the process of theoretical generalizations and the formation of conclusions); methods of statistical, structural, and factor analysis (in the process of studying the structure and dynamics of the development of ecological networks); empirical research methods (comparison) are used. Official data from the State Statistics Service; laws and regulations of Ukraine were used. Changes in nature were evaluated through indicators of the dynamics of areas of the nature reserve fund, which form the national ecological network (National report on the state of the environment in Ukraine in 2015, 2017).

The purpose of the article is to determine problems of the formation of the national ecological network and directions of tourism development in the recreational and protected areas in the context of the transition to sustainable development.

\section{Results of the study of the state of formation of the national ecological network}

The National Program for National Ecological Network Development in Ukraine for 2000-2015 identified the main structural elements (natural regions and corridors) and its constituent elements, in particular, territories and objects of the natural reserve fund, the water fund land, wetlands, water protection zones, forest land, etc. In the regions of Ukraine, there are approved 8 regional schemes and 47 local schemes for the ecological network formation - in Zakarpattia (13), Zaporizhzhia (2), Luhansk (4), Lviv (1), Poltava (1), 
Ternopil (1), Kharkiv (24), Chernivtsi (1) regions. As of 2015, elements of eight natural corridors and one natural region have been processed, namely: the scientific elaboration of measures for the creation and development of the Carpathian Ecological Network as a part of the Pan-European Ecological Network is conducted; the substantiation of the spatial localization of the Halytsko-Slobozhanskyi Interregional Transboundary Eco-Corridor is carried out; the concept of the regional scheme for the formation of the ecological network of the Dniester river meridian ecocorridor was developed and the map of the corridor was prepared; the concept of a regional scheme for the formation of the ecological network of the Polissia EcoCorridor was developed.

Scientists have prepared a conceptual framework for the structure and components of the Azov-Black Sea Ecological Corridor; within the framework of international projects, proposals were made for the creation of the ecosystem of Southern Bessarabia, prepared the concept of the Dnipro River Eco-Corridor, elements of the Desna River Natural Corridor were worked out, an indicative map of the Southern Bug Meridian Eco-Corridor was prepared. The scheme of the Turka Eco-Corridor (for the migration of bison, brown bear, lynx, wild boar, and other wildlife between protected areas of Poland and Skolivski Beskydy National Park) and the scheme of the Bukovinian Eco-Corridor (between Vizhnitsky National Park and Vânători-Neamț Natural Park (Romania)) for the restoration of natural ecosystem connections (ecocorridors) between populations of bison, bears, and lynx in Ukraine and Romania were developed and approved by the decisions of the relevant local governments.

Studies indicate the existence of transboundary biosphere reserves (TBRs) of Ukraine with neighbouring countries: the Ukrainian-Polish-Slovak TBR "East Carpathians" along with the Ukrainian Uzhanian National Nature Park and Nadsyansky Regional Landscape Park; Ukrainian-Romanian TBR "Danube Delta" along with the Ukrainian Danube Biosphere Reserve; Ukrainian-Belorussian-Polish TBR "West Polesie" along with the Ukrainian Shatsky National Natural Park; as well as: the transboundary Ukrainian-Slovak-German serial object of the UNESCO World Heritage Site "The Primeval Beech Forests of the Carpathians and the Ancient Beech Forests of Germany" with sites of the Carpathian Biosphere Reserve and Uzhanian National Nature Park; the transboundary Ukrainian-Belarussian wetlands "Stokhid-PripyatProstyr" and the Ukrainian wetlands of international significance "Pripyat River Floodplain" and "Stokhid River Floodplains". The increase in the area of the ecological network was also due to the expansion of the area of forest plantations (National report on the state of the environment in Ukraine in 2015, 2017). Such an approach to building a national ecological network comply with the concept of "green infrastructure", which involves integrated environmental landscape planning, considering the account of ecological networks, the environment, and biodiversity (De Montis et al., 2016).

These studies indicate that all of Ukraine's forests belong to the ecological network. According to the data of the state registration of forests (1996 and 2011), the area covered with forest vegetation increased by 173.7 thousand hectares (from 9400.2 thousand hectares to 9573.9 thousand hectares), and forest cover percent increased from $15.6 \%$ to $15.9 \%$. At the same time, this increase was restrained by insufficient financing and limited allocation of land for their creation. During the same period, the area of territories and objects of the natural reserve fund in the forests of the state increased by 277 thousand hectares (from 987 thousand hectares to 1264 thousand hectares) and the area of forests reserve increased from $13.9 \%$ to $15.7 \%$. In 2015, the territory of the newly created NNP "Nyzhnodniprovskyi" included 30.7 thousand hectares (including 13.4 thousand hectares with the seizure) of the lands of forest enterprises. The area of field protection zones as of 01.01.2016 is 446.7 thousand hectares, the area of other protective stands is 1042.0 thousand hectares (as of 01.01.2015, respectively, it was 446.1 and 1034.8 thousand hectares).

According to the State Statistics Service of Ukraine, in 2015, forests were restored on an area of 60.4 thousand hectares (by $4.1 \%$ more than in 2014); in particular, planting of forests is conducted in the area of 2.5 thousand hectares (National report on the state of the environment in Ukraine in 2015, 2017). The composition of the land belonging to the national ecological network of Ukraine is given in Table 1.

Data analysis shows that the area of land belonging to the ecological network components increased by 201.3 thousand hectares (or 3.9\%) compared to 2000, but since 2014 this area has decreased by 0.6 thousand hectares. The area of forests and area covered by forest increased by 2.8 thousand hectares, and the area of grassland and pasture decreased by 7.8 thousand hectares.

At the same time, there is a tendency to increase the area of arable land, since 2014 it has increased by 15.8 thousand hectares and is 32541.3 thousand hectares. Compared to 2014, the area of land under open development, quarries, mines, and related structures (157.1 thousand hectares) has increased by 0.8 thousand hectares, and the land area used for transport and communication (496.8 thousand hectares) has increased (by 0.1 thousand hectares). Remain unchanged: the area of land under temporary preservation (amounting to about 7.2 thousand hectares); lands under land reclamation and fertility restoration decreased by 0.3 thousand hectares (are about 55.6 thousand hectares); green areas of common use (totalling 91.0 thousand hectares) decreased by 
Table 1

The composition of the land belonging to the national ecological network of Ukraine

\begin{tabular}{|l|c|c|c|c|}
\hline \multicolumn{1}{|c|}{ Components } & $\begin{array}{c}\text { Area (thousand } \\
\text { hectares) as of } \\
01.09 .2000\end{array}$ & $\begin{array}{c}\text { Area (thousand } \\
\text { hectares) as of } \\
01.01 .2015\end{array}$ & $\begin{array}{c}\text { Area (thousand } \\
\text { hectares) as of } \\
01.01 .2016\end{array}$ & $\begin{array}{c}\text { Forecast area (thousand } \\
\text { hectares) by 2015 }\end{array}$ \\
\hline Grasslands and pastures & 7772,9 & 7848,3 & 7840,55 & 9536,6 \\
\hline Forests and area covered by forests & 10380,2 & 10630,3 & 10633,1 & 10955,7 \\
\hline Open wetlands & 940,4 & 982,6 & 982,3 & 1340,4 \\
\hline $\begin{array}{l}\text { Radioactive contaminated land that } \\
\text { is not used in the economy }\end{array}$ & 136,0 & 123,8 & 123,7 & 1180,8 \\
\hline $\begin{array}{l}\text { Open lands without plant cover or } \\
\text { with insignificant vegetation cover }\end{array}$ & 1180,8 & 1015,8 & 1020,6 & 2415 \\
\hline Waters & 2415 & 2426,4 & 2426,4 & 25164,5 \\
\hline $\begin{array}{l}\text { Total area (thousand hectares), the } \\
\text { share of the total area of Ukraine }\end{array}$ & 22825,3 & 23027,2 & 23026,6 & $41,68 \%$ \\
\hline
\end{tabular}

Source: based on Derzhavnyj komitet statystyky Ukrainy, 2017

0.2 thousand hectares (National report on the state of the environment in Ukraine in 2015, 2017).

The main environmental risks (threats) of the biodiversity of the ecological network of Ukraine are anthropogenic factors, which are classified into three groups: 1) direct physical destruction: hunting, fishing, felling, flooding of indigenous herbal vegetation types, overpopulation, fire, targeted burning, ploughing, quarrying, recreation and urbanization; 2) change of natural environments: sylvatization, reserve succession, fragmentation of ecotopes, modification of location; 3) pollution: biological, communal.

Also, the main threat to biodiversity in the forests is the effects of climate change. Climate change processes cause an increase in the number of extreme weather events that have a negative impact on forests and forestry (increased forest fires, harmful insects, and outbreaks of diseases, the spread of windbreaks and hurricanes, worsening of the situation with drought). Poaching and unauthorized felling are also one of the major threats to biodiversity. The degradation of the forest cover, despite some increase in its area, the increase in the area of eroded soils, and the decrease in the number of hunting species remain negative trends. As a result of declining cattle numbers throughout the country, successional changes occur in steppe and wetland ecosystems. Lack of grazing leads to overgrown swamp ecosystems with shrubs, which in turn leads to a reduction in the areas of natural habitats of many species of animals and plants, including those included in the Red Data Book of Ukraine (National report on the state of the environment in Ukraine in 2015, 2017).

The World Economic Forum has prepared and published the results of this year's global survey with its ranking of countries around the world on the level of environmental performance. The ranking is based on the 2018 Environmental Performance Index 2018 (The Environmental Performance Index, 2018), which reflects the achievements of countries in the field of management of natural resources and their rational use. The Ecological Efficiency Index 2018 assesses the state of the environment and the viability of ecosystems in 180 countries of the world. This year, Switzerland has been recognized as the leader in terms of environmental efficiency. The top ten leaders also included France, Denmark, Malta, Sweden, Great Britain, Luxembourg, Austria, Ireland, and Finland. Ukraine ranked 109th in the ranking and found itself between Turkey (108) and Guatemala (110). This year, the Index of Ukraine made 52.87 points. In addition, the worst value was given to an indicator that estimates the loss of our forest cover (14.08). In addition, the number of indicators is estimated to be less than 50 points, for example - biodiversity and habitat - 49.10 points (Pozyciyi Ukrayiny v rejtynhu ekolohichnoyi tõhusnosti u 2018 roci, 2018).

Thus, the ecological framework of the territory in most regions of Ukraine requires the development of additional environmental protection measures. According to specialists, the ecological framework of the territory is a set of its ecosystems with an individual regime of nature management for each site that forms a spatially organized infrastructure that supports the ecological stability of the territory, preventing the loss of biodiversity and degradation of the landscape. The ecological framework carries out its functions in the presence of appropriate legal, economic, and managerial mechanisms that should be related to the existing level of economic infrastructure and technologies of nature management (Elizarov, 1998).

For carrying out the effective policy of preserving biological and landscape diversity in the modern environment, it is necessary to more accurately elaborate on the existing general schematic model of the ecological network of Ukraine and a number of models of ecological networks of regional levels (Shvaiko, Maniuk, 2017). Specialists also pay attention to the implementation of international experience in 
the formation of ecological networks. In modern times, the European ecological network "Natura 2000" is the main means of preservation and protection of flora and fauna and natural habitats in Europe (Vashchyshyn, 2014).

\section{Economic problems of environmental protection and priority directions of sustainable development of "green" tourism}

The study of state statistics on the costs of environmental protection indicates that in 2016, Ukraine's enterprises, organizations, and institutions spent 32.5 billion UAH on environmental protection and in $2015-24.6$ billion UAH respectively. In the total volume of Ukraine's capital investments in environmental protection, investments in integrated technologies make up 59\%, cleaning - 40\%, and other investments $-1 \%$. As in previous years, the main source of financing of environmental protection expenses was the own funds of enterprises and organizations $-68 \%$, at the expense of the state and local budgets $-6 \%$ of expenditures were financed, and the remaining funds came from other sources of financing (Costs for the protection of the environment in 2016, 2017).

At the same time, we draw attention to the fact that the share of expenditures on research and development in environmental protection in the general structure is almost $2 \%$, which is extremely not enough for scientific support of measures for the formation of the ecological framework of the state territories (Table 2).

Data analysis indicates that capital investment in air protection and climate change prevention has tripled in comparison with 2006 (Table 3).

But for the further development of the ecological network in the country, it is necessary to ensure the attraction of additional investments, an effective system of environmental protection, overseeing the recreational areas associated with the functional territorial system of ecological stability. At present, the European Union has launched another initiative to build a "green infrastructure" for ecosystem services (Izakovičová and Świąder, 2017). According to UN experts, ecosystem services represent a lot of benefits that nature puts on society. Biodiversity - a diversity that is observed among living organisms, which is vital for the functioning of ecosystems and the provision of services. Ecosystem services create opportunities for people's lives, for example by providing them with food rich in calories and clean water, regulating diseases and climate, promoting pollination of crops and soil formation, as well as providing recreational, cultural, and spiritual needs of the population. Despite its estimated value of 125 trillion USD, these assets do not find proper accounting in the political and economic life, that is, investment in their protection and management is insufficient (Ecosystem Services \& Biodiversity, 2018).

Ukraine has a very strong potential for the development of ecosystem tourism services in recreational areas. As of 01.01.2016, the country has 649 territories and objects of the NRF of national importance: 19 natural and 4 biosphere reserves, 49 national nature parks, 310 forest reserves, 134 natural monuments, 18 botanical gardens, 7 zoological parks, 19 dendrological parks, park-monuments of garden art. Their total area was 2244.18 thousand hectares (within the territory of Ukraine) or $54.97 \%$ of the total area of the NRF and $3.56 \%$ of the territory of Ukraine. The number of territories and objects of the NRF of local significance was 7555 units with an area of 1.84 million hectares. The share of areas of territories and objects

Table 2

Costs of protection and rational use of natural resources in 2016

\begin{tabular}{|c|c|c|c|c|}
\hline \multirow{3}{*}{$\begin{array}{c}\text { Costs of protection and rational use } \\
\text { of natural resources by directions, } \\
\text { thousand UAH }\end{array}$} & \multirow{3}{*}{ Total } & \multicolumn{3}{|c|}{ Including } \\
\hline & & \multicolumn{2}{|c|}{ capital investments } & \multirow{2}{*}{ current expenses } \\
\hline & & total & of them for major repairs & \\
\hline Total & 32488702,1 & 13390477,3 & 612636,1 & 19098224,8 \\
\hline \multicolumn{5}{|l|}{ including for } \\
\hline $\begin{array}{l}\text { atmospheric air protection and climate } \\
\text { change problems }\end{array}$ & 4263419,2 & 2502805,8 & 181832,1 & 1760613,4 \\
\hline cleaning of return water & 8960117,4 & 1160029,1 & 248189,4 & 7800088,3 \\
\hline waste management & 8928254,3 & 2208676,6 & 32473,3 & 6719577,7 \\
\hline $\begin{array}{l}\text { protection and rehabilitation of soil, } \\
\text { underground and surface water }\end{array}$ & 1617183,2 & 419988,9 & 100903,1 & 1197194,3 \\
\hline $\begin{array}{l}\text { reduction of noise and vibrational } \\
\text { influence }\end{array}$ & 361994,2 & 94788,5 & 43263,2 & 267205,7 \\
\hline conservation of biodiversity and habitat & 594125,8 & 49577,9 & 1843,9 & 544547,9 \\
\hline radiation safety & 7053479,2 & 6943976,2 & 76,9 & 109503,0 \\
\hline $\begin{array}{l}\text { research and development in } \\
\text { environmental protection }\end{array}$ & 58649,5 & 2435,1 & - & 56214,4 \\
\hline other areas of environmental activity & 651479,3 & 8199,2 & 4054,2 & 643280,1 \\
\hline
\end{tabular}

Source: based on Derzhavnyj komitet statystyky Ukrainy, 2017 
Vol. 4, No. 4, 2018

Baltic Journal of Economic Studies

Table 3

Capital investments for environmental protection in the areas of environmental protection measures (2006-2016)

\begin{tabular}{|c|c|c|c|c|c|c|}
\hline \multirow{2}{*}{ Years } & $\begin{array}{c}\text { Total, thousand } \\
\text { UAH }\end{array}$ & $\begin{array}{c}\text { atmospheric air } \\
\text { protection and } \\
\text { climate change } \\
\text { prevention }\end{array}$ & $\begin{array}{c}\text { cleaning of return } \\
\text { water }\end{array}$ & waste management & $\begin{array}{c}\text { protection and } \\
\text { rehabilitation of } \\
\text { soil, underground } \\
\text { and surface water }\end{array}$ & other measures \\
\hline 2006 & 2194188,5 & 762538,6 & 777924,5 & 339529,6 & 247695,4 & 66500,4 \\
\hline 2007 & 3080687,6 & 1379250,6 & 809677,1 & 388386,6 & 393036,8 & 110336,5 \\
\hline 2008 & 3731400,4 & 1476343,3 & 927352,9 & 422918,6 & 787303,8 & 117481,8 \\
\hline 2009 & 3040732,7 & 1273789,4 & 882525,4 & 400016,9 & 401425,6 & 82975,4 \\
\hline 2010 & 2761472,1 & 1139946,7 & 734663,4 & 475584,3 & 319922,0 & 91355,7 \\
\hline 2011 & 6451034,6 & 2535632,6 & 721325,5 & 1183880,2 & 639123,1 & 1371073,2 \\
\hline 2012 & 6589336,5 & 2462675,3 & 846955,4 & 730544,4 & 540516,8 & 2008644,6 \\
\hline 2013 & 6038783,0 & 2411935,1 & 834114,8 & 713856,3 & 324980,1 & 1753896,7 \\
\hline $2014^{1}$ & 7959853,9 & 1915129,7 & 1122149,3 & 783965,4 & 359925,6 & 3778683,9 \\
\hline $2015^{1}$ & 7675597,0 & 1422946,6 & 848881,2 & 737498,9 & 388259,2 & 4278011,1 \\
\hline $2016^{1}$ & 13390477,3 & 2502805,8 & 1160029,1 & 2208676,6 & 419988,9 & 7098976,9 \\
\hline
\end{tabular}

${ }^{1}$ Excluding the temporarily occupied territory of the Autonomous Republic of Crimea, the city of Sevastopol, and a part of the zone of the anti-terrorist operation.

Source: based on Derzhavnyj komitet statystyky Ukrainy, 2017

of certain categories in the NRF included: nature reserves $-5.03 \%$, biosphere reserves $-6.18 \%$, national nature parks $-32.13 \%$, forest reserves $-33.89 \%$, nature monuments $-0.71 \%$, regional landscape parks $-19.25 \%$, protected ecosites $-2.40 \%$, botanical gardens $-0.05 \%$, zoological parks $-0.01 \%$, dendrological parks $-0.04 \%$, park-monuments of garden art - $0.32 \%$. The share of the NRF areas from administrative units' areas ("reserve index") varied considerably. The lowest - up to $5 \%$ - it was in Vinnytsia, Dnipropetrovsk, Donetsk, Zhytomyr, Zaporizhzhia, Kyiv, Kirovohrad, Luhansk, Mykolaiv, Odesa, Poltava, Cherkasy, Kharkiv regions, the highest - more than $12 \%$ - in Ivano-Frankivsk, Khmelnytskyi, Zakarpattia, and Chernivtsi regions, while in Kyiv and Sevastopol it was 14.9\% and 30.3\% respectively. In Volyn, Lviv, Rivne, Sumy, Ternopil, Kherson, Chernihiv regions and the Autonomous Republic of Crimea - 6-12\%. Thus, in the various regions of Ukraine, the reserve index in 2015 ranged from 2.24 to $15.71 \%$ (National report on the state of the environment in Ukraine in 2015, 2017).

Regional studies on the development of ecosystem services and recreation and tourism activities in the regions of Ukraine show that with the assistance of the EU, two large-scale cross-border tourism projects in the Ivano-Frankivsk region have been implemented: "Development of Cross-Border Tourism and Network in Ivano-Frankivsk (Ukraine) and Maramureș (Romania)" and "VeloKraina". Within the framework of the first of them, the Centre for Ecotourism is organized in Yaremche, and the second is aimed at developing a network of hiking and cycle routes in the region. The partners of the VeloKraina project are the Carpathian National Nature Park, local community organizations, and the Asociatia Pentru Turism Cultura Si Tineret, a Romanian partner organization. The project was implemented within the framework of the Cross-Border Cooperation Program "Romania - Moldova - Ukraine". The experience of implementing the FORZA project deserves attention - a comprehensive environmental, social, and economic project, where tourism development is defined as one of the means of raising the population's income in Transcarpathia. Owning to the project, the Tourist Information Centre in Rakhiv and the Transcarpathian Tourist Path in the Rakhiv district were created. Thanks to this project, the Rakhiv Forestry, and the Carpathian Biosphere Reserve in cooperation with the mountain district administrations, about $80 \mathrm{~km}$ of the Transcarpathian Tourist Path was organized (Lintur, Kampov and Kasinets, 2018).

Note that according to international experts, the modern trends of "green" tourism in the conditions of sustainable development are recognized: 1) farm tourism - as a rapidly growing market of services, which allows residents to connect with nature; 2) tourism in protected areas with water areas and fishing villages; recreational fishing services are a growing tourism industry with approximately 118 million fishermen in the developed world; 3 ) natural tourism in forests is an important factor to be taken into account in regional planning and management of forestry activities. Tourism revenues can be an incentive to implement sustainable forest management measures (Ecosystem Services and Biodiversity, 2018).

In the context of the problems considered, the tourism and recreation sector is an important sector of the national economy and a tool for the development of nature-recreational areas. Thus, revenues from the tourist tax in Ukraine in 2016 increased by $45.7 \%$ compared to 2015 and amounted to 54.1 million UAH. According to 
the Ministry of Economic Development and Trade, the largest share of the paid tourist tax in 2016 fell to Kyiv $27.2 \%$, in the second place - Lviv region with $15.6 \%$, in the third - Odesa with $13.6 \%$. According to the State Fiscal Service, the total amount of tax payments from entities in the field of tourism and resorts in 2016 increased by $45.5 \%$ compared to 2015 and amounted to 2.496 billion UAH. The share of tax payments from the activity of hotels and other temporary accommodation means in the total amount of taxes paid in the field of tourism in 2016 amounted to $39.8 \%$ or 992.886 million UAH. Compared to 2015, the volume of such revenues increased by 1.6 times (Payment of tourist tax in Ukraine in 2016 increased by $45.7 \%, 2017)$.

\section{Conclusions}

Research conducted has shown that the main goal of building an ecological network in Ukraine is to preserve the landscape and biological diversity and create new objects of the nature reserve fund. State and regional policy on environmental protection, rational use of natural resources, provision of ecological safety of human life, ecologization of activity of recreation and tourism establishments should become the inalienable conditions for sustainable economic and social development of recreational territories. Therefore, in the future, the state authorities need to form regional economic mechanisms for attracting investments in the field of environmental protection, stimulating users of natural resources to reduce the harmful impact on the environment, promoting rational and economical use of natural resources, the introduction of "green" tourism aimed at developing a network of hiking and cycle routes. In the regions of Ukraine, it is necessary to develop balanced approaches to the use of the potential of nature conservation area of tourist nature use, international experience in implementing cross-border tourism projects in the Carpathian National Nature Park, and to form integrated investment regional tourism projects of ecological orientation. The introduction of green tourism development lines will have a positive effect on the formation of ecological networks. Particularly, these measures are necessary to find additional investments for environmental protection measures and the development of ecological networks in the regions of Ukraine.

\section{References:}

De Montis, A., Caschili, S., Mulas, M., Modica, G., Ganciu, A., Bardi, A., Ledda, A., Dessena, L., Laudari, L. \& Fichera C. R. (2016). Urban - rural ecological networks for landscape planning. Land Use Policy, 50, 312-327.

Denysyk, H. I. (2010). Development of Ecological Network in Ukraine: problems in terms geographer [Rozbudova ekolohichnoyi merezhi Ukrayiny: problemy z pohlyadu heohrafa]. Journal of Kharkov National University V.N. Karazin, no. 93(8), pp. 19-22. (in Ukrainian)

Ecosystem Services and Biodiversity (2018). Retrieved from: http://www.fao.org/ecosystem-servicesbiodiversity/en/ (accessed May 2018)

Elizarov, A. (1998). Ecological framework - strategy steppe wildlife of the XXI century. Retrieved from: https:// www.biodiversity.ru/programs/steppe/bulletin/step-2/step2-2.html (in Russian) (accessed May 2018)

Graham, Bennett (2004). Integrating Biodiversity Conservation and Sustainable Use: Lessons Learned From Ecological Networks. Cambridge, UK. Retrieved from: http://www.cenn.ge/electronic library/Biodiversity/ Integrating\%20Biodiversity\%20Conservation\%20and\%20Sustainable\%20Use.pdf (accessed May 2018)

Izakovičová, Zita, and Małgorzata Świąder (2017). Building Ecological Networks in Slovakia and Poland. Ekológia (Bratislava), 36(4), 303-322.

Jongman, Rob H. G., Mart Külvik and Ib Kristiansen (2004). European ecological networks and greenways. Landscape and urban planning, 68(2-3), 305-319.

Paul Opdam, Eveliene Steingröver, and Sabine Van Rooij (2006). Ecological networks: a spatial concept for multiactor planning of sustainable landscapes. Landscape and urban planning, 75(3-4), 322-332.

Kapitalni investyciyi na okhoronu navkolyshnoho pryrodnoho seredovyshha za napryamamy pryrodookhoronnykh zakhodiv (2017). [Capital investment in the protection of the environment in the areas of environmental protection measures] Retrieved from: http://www.ukrstat.gov.ua (accessed May 2018) (in Ukrainian)

Lintur, I. V., Kampov, N. S., Kasynec, O. V. (2018). Investycijni proekty rozvytku turystychnoho kompleksu [Investment projects of development tourist complex of Ukraine] Ekonomika $i$ suspilstvo [Economy and society], no. 14, pp. 613-618. (in Ukrainian)

Nacionalna dopovid pro stan navkolyshnoho pryrodnoho seredovyshha v Ukrayini u 2015 roci (2017). [National report on the state of the environment in Ukraine in 2015]. Ministerstvo ekolohiyi ta pryrodnykh resursiv Ukrayiny, 308 p. (in Ukrainian)

Payment of tourist tax in Ukraine in 2016 increased by 45.7\% (2017). Retrieved from: https://interfax.com.ua/ news/economic/416390.html (accessed May 2018)

Pozyciyi Ukrayiny v rejtynhu ekolohichnoyi efektyvnosti u 2018 roci (2018). [The position of Ukraine in the rating of environmental efficiency in 2018] Retrieved from: http://edclub.com.ua/analityka/pozyciyi-ukrayiny-vreytyngu-ekologichnoyi-efektyvnosti-u-2018-roci (accessed May 2018) (in Ukrainian)

Serova, O. V., Kulagina, A. F. (2014). Ural-Volga region: natural potential of its territories and environmental risks in the sphere of tourism. Povolzhskiy Journal of Ecology, 1, 146-151. (in Russian) 
Sheliah-Sosonko, Yu. R. (1999). Holovni rysy ekomerezhi Ukrayiny [Main features of the ecological network of Ukraine]. Rozbudova ekomerezhi Ukrayiny. Kyiv, 13-22. (in Ukrainian)

Sheliah-Sosonko, Y. R., Tkachenko, V. S., Andriyenko, T. L., Movchan, Y. I. (2005). Ekomerezha Ukrayiny ta yiyi pryrodni yadra Econet of Ukraine and its natural nucleus [Econet of Ukraine and its natural nucleus]. Ukr. Botan. Zh., no. 62(2), pp. 142-158. (in Ukrainian)

Shvaiko, V. M., Maniuk, V. V. (2017). Strukturuvannya ekomerezhi na subrehionalnomu rivni (Pokrovskyj ta Mezhivskyj rajony Dnipropetrovskoyi oblasti) [The Ecological Network of the subregional level of Dnipropetrovsk region (Pokrovsky and Mezhyvsky districts)]. Visnik Dnipropetrovskogo universitetu. Seria Geologia, geographia Dnipropetrovsk University Bulletin. Series: geology, geography, no. 25(1), pp. 119-130. (in Ukrainian)

Nacionalna dopovid pro stan navkolyshnoho pryrodnoho seredovyshha v Ukrayini u 2015 roci (2017). [National report on the state of the environment in Ukraine in 2015], 308 p. (in Ukrainian)

Vashchyshyn, M. (2014). Pravovi j orhanizacijni zasady formuvannya nacionalnoyi ekolohichnoyi merezhi $\mathrm{v}$ Ukrayini [Legal and organizational principles of forming the national environmental network in Ukraine]. Naukovyj visnyk Mizhnarodnoho humanitarnoho universytetu. Ser.: Yurysprudenciya, no. 10-1(2), pp. 52-55. (in Ukrainian)

Vytraty na okhoronu ta racionalne vykorystannya pryrodnykh resursiv za napryamamy pryrodookhoronnykh vytrat u 2016 roci (2017). [Costs of protection and rational use of natural resources in the areas of environmental protection expenditures in 2016]. Retrieved from: http://www.ukrstat.gov.ua (accessed May 2018) (in Ukrainian) 